\title{
高脂肪食摂取ラットにおける脂質代謝に及ぼす 鰹節タンパク質麦匊分解物投与の影響
}

\author{
田中将行*1 上甲孝志 ${ }^{* 1} \cdot$ 池田博明*1 \\ 片 岡二 郎*2. 安原 義*3・古庄 律*3
}

\section{Intake of Dried Bonito (Katsuo-Bushi) Protein Koji Hydrolysate Accelerates Lipid Metabolism of Rats Fed High-Fat Diet}

\author{
TANAKA Masayuki*1, Joukou Takashi*1, IkedA Hiroaki*1, \\ KataoKa Jiro $^{* 2}$, Yasuhara Tadashi ${ }^{* 3}$ and Furusho Tadasu*3 \\ * 1 Department of Research and Development, Yamaki Co., Ltd. \\ 1698-6, Kominato, Iyo-shi, Ehime 799-3194 \\ * 2 Consulting Engineer \\ 6-29-7, Shinyoshidahigashi, Kohoku-ku, Yokohama-shi, Kanagawa 223-0056 \\ * 3 Department of Nutrition, Jr. College of Tokyo University of Agriculture \\ 1-1-1, Sakuragaoka, Setagaya-ku, Tokyo 156-8502
}

\begin{abstract}
We examined the effect of dried bonito protein koji hydrolysate $(\mathrm{KH})$ intake on the lipid metabolism of rats fed a high-fat (HF) diet. The rats were divided into four groups. The first group was given the control diet, the second group, a HF diet containing 30\% lard, the third group, a HF diet containing $5 \% \mathrm{KH}$, the fourth group, a $\mathrm{HF}$ diet containing $5 \% \mathrm{KHL}$ (KHL: $\mathrm{KH}$ in which TFF was filtered). These experimental diets were given for 4 weeks. Consequently, the body and circumference (kidney) adipose tissue weights of the $\mathrm{HF}+\mathrm{KH}$ and $\mathrm{HF}+\mathrm{KHL}$ groups were lower than those of the $\mathrm{HF}$ group. The serum TG and NEFA levels of the $\mathrm{HF}+\mathrm{KH}$ and $\mathrm{HF}+\mathrm{KHL}$ groups were also significantly lower than those of the HF group. However, as regards serum cholesterol level, there was no difference between the four groups. The liver G 6 PD activities of the $\mathrm{HF}, \mathrm{HF}+\mathrm{KH}$, and $\mathrm{HF}+\mathrm{KHL}$ groups were higher than that of the control group. Moreover, the liver ACO activities of the $\mathrm{HF}+\mathrm{KH}$ and $\mathrm{HF}+$ KHL groups were in higher than that of the HF group. These results suggest that either KH or KHL intake accelerates the lipid metabolism of rats fed a high-fat diet.
\end{abstract}

(Received Jan. 23, 2006 ; Accepted Jun. 5, 2006)

鰹節は槒油や味噌と並び日本独特の伝統的食材であり, 日本はもとよりミクロネシア地域に至る広範囲に天然調 味料として有史以来重要な調味料として定着している。 しかし，近年はこの鰹節を家庭で削る手間を省くことか ら削り節として使用する機会が多くなり,さらに加工食 品や利便性を求めた調味料として, 工場で鰹節からだし を抽出した䚛エキスや榇油等と混合して「つゆ」とした 製品の需要が急速に増加している。この鰹節からだしを 抽出した後に多量の鏗節抽出残渣 (Katuobushi Extract Residue：以下KER）が発生し, 産業廃棄物として処理
に苦虑している。これまで食品への利用方法として一部 は酵素処理等でエキス化されているが，主に飼料・肥料 として利用されているのが現状である ${ }^{11}$ 。KERの風味お よび呈味成分に関しては，だしの抽出残渣であるために ほとんど残っていないが，タンパク質含量（無水物換算 值）は約 $80 \%$ と高く, 栄養価は牛乳由来のカゼインとほ ぼ同等であり ${ }^{2)}$, 良質なタンパク質含量の高い食品素材 である。これまで, 魚類のタンパク質には, マグロ筋肉 タンパク質のコレステロール上昇抑制作用施およびイワ シ筋肉タンパク質等の抗高血圧作用 ${ }^{4}$ が知られており,

\footnotetext{
* 1 ヤマキ(株)（７799-3194 愛媛県伊予市米湊1698-6 )

E-mail：田中将行；matanaka@yamaki.co.jp，上甲孝志；tjyoukou@yamaki.co.jp，池田博明 ; hikeda@yamaki.co.jp

* 2 片岡二郎・技術士事務所（－223-0056 神奈川県横浜市港北区新吉田東 6-29-7）

E-mail : Jiroukataoka@nifty.ne.jp

*3 東京農業大学短期大学部栄養学科（†156-8502 東京都世田谷区桜丘 1-1-1）

E-mail : 安原義 ; yasuhara@nodai.ac.jp, 古庄律 ; tfurusho@nodai.ac.jp
} 
鰹節タンパク質においては, その酵素分解物が抗酸化作 用 ${ }^{5)}$, また抗高血圧作用 ${ }^{6)}$ の存在することが報告されてい る。しかしながら, 鑑節を酵素分解したものは苦味が強 く, 風味やコク味も少ないことなど欠点もあり, 食品素 材として使用するには改良の余地が残されているように 思われた。

そこで私たちは，日本の伝統的な発酵食品を製造する 際に使用する銤菌を用いて, そのプロテアーゼの作用に よってKER中のタンパク質を分解することで風味やコ ク味が向上し，また既製品との差別化が図れるのではな いかと考えて製品開発を試みた。その結果, 既製品と比 較して風味等で優れた製品を製造することに成功した7)。 また，この製品については自然発症高血圧ラット （SHR）に経口投与したところ血圧降下作用を示すぺプ チド画分が存在することを確認した ${ }^{8)}$ 。一方, 食品に由 来するペプチドの機能性に関する研究は, 近年非常に盛 んになってきており, 特に大豆タンパク質由来ぺプチド には血圧降下作用以外に体脂肪や血中コレステロールの 抑制作用が報告されており ${ }^{9)}$ ，大豆夕ンパク質由来ぺプ チド以外のペプチドにもそれらの機能性が備わっている ことも考えられた。

本研究では, 䉯節タンパク質由来ペプチド含有量の高 い本製品のさらなる食品機能を検索する一環として, 高 脂肪添加飼料を投与したラットを用いて, KER麦菌由 来酵素分解物の脂質代謝に対する影響について検討した。

\section{実験方法}

\section{KER麦料由来酵素分解物の調製}

KERは鰹節の粉末（10mmッシュパス）を沸騰水中 で熱水抽出処理し, チョッパー（増幸産業社製）で微細 処理したものを用い, 瞵は原料に小麦焚を用いて回転式 通気無菌固体培養装置（フジワラテクノアート社製）で 作成した無菌固体錮（雑菌の生育のない銤）を使用した。 調製方法はKER $120 \mathrm{~g}$ （粗タンパク質含量 $37.6 \%$ ）と水 $240 \mathrm{~m} \ell$ 混合後, $121^{\circ} \mathrm{C} 30$ 分間滅菌処理を行い, 瞵 $12 \mathrm{~g}$ （粗タンパク質含量 $12.6 \%$ ）を混合し， $50{ }^{\circ} \mathrm{C}$ で 3 日間， 無塩条件下で分解した。分解終了後の上清を熱風乾燥し たものをKER銤分解物（以後KHと略す）とした。また， KER麦匊分解液を膜モジュール（PLAC：ミリポア）を用 いてクロスフローろ過（以後TFFろ過と略す）により 分子量 $1 \mathrm{kd}$ 以下の画分を濃縮し, 熱風乾燥したKER麦匊 分解物限外万過物（以後KHLと略す）を調製して飼料 中に添加した。

\section{2 . 飼料調製法}

実験用飼料の配合はTable 1 に示すように, AIN76標 準飼料組成を基準に正常食 (Control食) を調製した。 高脂肪食 (HF食) は, ラードを飼料中に $30 \%$ 添加して 調製した。HF食にKHを $5 \%$ 添加したものを $\mathrm{HF}+\mathrm{KH}$ 食 とし，HF食にKHLを $5 \%$ 添加したものをHF+KHL食と した。
Table 1 Compositions of Experimental Diets (\%)

\begin{tabular}{lrrrc}
\hline & Control & \multicolumn{1}{c}{ HF } & HF+KH & HF+KHL \\
\hline Casein & 20.0 & 20.0 & 15.0 & 15.0 \\
KH & 0.0 & 0.0 & 5.0 & 0.0 \\
KHL & 0.0 & 0.0 & 0.0 & 5.0 \\
Corn Starch & 65.0 & 40.0 & 40.0 & 40.0 \\
Oil (Lard) & 5.0 & 30.0 & 30.0 & 30.0 \\
Cellulose & 5.0 & 5.0 & 5.0 & 5.0 \\
Vitamin Mix* & 1.0 & 1.0 & 1.0 & 1.0 \\
Mineral Mix & 3.5 & 3.5 & 3.5 & 3.5 \\
Choline Chloride & 0.2 & 0.2 & 0.2 & 0.2 \\
DL-Methionine & 0.3 & 0.3 & 0.3 & 0.3 \\
\hline Total & 100.0 & 100.0 & 100.0 & 100.0 \\
\hline
\end{tabular}

* Vitamin Mix and Mineral Mix were obtained from Oriental Yeast Co., LTD (Tokyo, Japan)

\section{3. 実験動物および飼育条件}

5 週歯令のSprague-Dawly（SD）系雄性ラット(体重： $107 \pm 5 \mathrm{~g}$ : 東京実験動物 (株) より購入) を実験動物と して用い，各群 6 匹の平均体重が等しくなるように Control食群, $\mathrm{HF}$ 食群, $\mathrm{HF}+\mathrm{KH}$ 食群, $\mathrm{HF}+\mathrm{KHL}$ 食群の 4 群に分け, 室温 $22 \pm 2{ }^{\circ} \mathrm{C}, 12$ 時間毎の明暗サイクルの 環境下で個別ゲージを用い 4 週間飼育した。飼料給餌法 は制限給餌とし， 4 週まで $15 \mathrm{~g} /$ 日/匹とした。給水は水 道水を自由摂取させた。飼育期間中は毎日一定時刻に体 重を測定した。飼育終了日にネンブタール麻酔下で心臓 採血法により屠殺後, 解剖により肝臓, 腎周囲脂肪組織 を摘出した。また, 採血した血液は, 血清分離管（セパ ラピッドチューブ 積水化学) を用いて $2,500 \mathrm{rpm}$ で 15 分間遠心分離して血清を調製した。

\section{4. 血清中トリグリセライド, 遊離脂肪酸, 総コレステ ロール, HDLーコレステロールの測定方法}

血清中トリグリセライド（TG）濃度は，GPO·DAOS 法 $^{10)}$ による測定キット(トリグリセライドEーテストワ コー，和光純薬工業製），血清中遊離脂肪酸（NEFA） 濃度はACS·ACOD法 ${ }^{11)} に よ る$ 測定キット（NEFAーテ ストワコー，和光純薬工業製）を用いて測定した。また， 血清中総コレステロール（T-Chol）濃度はコレステロ ールオキシダーゼ・ $p$-クロロフェノール法 ${ }^{12}$ による測 定キット（コレステロールCIIテストワコー，和光純薬 工業製)，血清中HDLーコレステロール（HDL-Chol） 濃度はへパリン・マンガン結合沈殿法 ${ }^{13)} に よ る$ 測定キッ ト（HDLーコレステロールテストワコー，和光純薬工 業製）用いて測定した。血清中LDLーコレステロール (LDL-Chol) 濃度は, T-Chol - HDL-Chol - (TG/ 5 ) で 与えられた計算式により求めた。

5. グルコースー6-リン酸脱水素酵素（G6 PD）の測 定方法 ${ }^{14)}$

肝蔵（1.0 g ）を 4 倍容の0.25M Sucrose溶液でホモ ジナイズした後， $7,000 \times \mathrm{g}$ で10分間遠心分離して得ら 
れた上清を粗酵素液とした。粗酵素液 $50 \mu \ell に 6.9 \mathrm{mM}$ $\mathrm{MgCl}_{2}, 1.0 \mathrm{mM} \mathrm{G} 6 \mathrm{P}, 0.39 \mathrm{mM}$ NADPを 含 む $86 \mathrm{mM}$

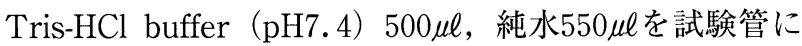
入れよく混和し，直ちに $340 \mathrm{~nm}$ の吸光度を測定した。試 料を $37^{\circ} \mathrm{C} て ゙ 3$ 分間反応させた後, 再び吸光度を測定し, この条件下で 1 分間当り $1 \mu \mathrm{mol}$ の NADPを還元するのに 要する酵素量を 1 活性単位（unit）とした。

\section{6. アシルCoAオキシダーゼ（ACO）の測定方法}

ACOの活性測定は，LAZAROW とD DuvEの方法の変 法 ${ }^{15)}$ に従って行った。0.17M DTT, 20mM NAD, 1.5\% Fatty acid free Albumin, 2.0\% Triton X-100, 10mM CoA, $1 \mathrm{mM}$ FAD, 100mM KCNを含む $50 \mathrm{mM}$ Tris- $\mathrm{HCl}$ buffer（pH8.0） 0.991mもを試験管にとり粗酵素液 $5 \mu \ell$ を加えて $37^{\circ} \mathrm{C}$ で予温した 2 分後に $340 \mathrm{~nm}$ 吸光度を測定し た。2.5mM Palmitoyl CoAを $4 \mu$ 加え， $37^{\circ} \mathrm{C} ゙ 5$ 分間 反応させた後，再び $340 \mathrm{~nm}$ の吸光度を測定した。この条 件下で 1 分間当り $1 \mu \mathrm{mol}$ のADHを生成するのに要する 酵素量を 1 活性単位（unit）とした。

\section{7. 統 計 処 理}

各項目のデータは, 統計処理ソフトStatcel 2 を用い てBonferroni/Dann法により多重比較検定を行い各群間 の有意差を検定した。なお，值はすべて平均值士標準誤 差で表した。

\section{実 験 結 果}

\section{1. 体重増加量の推移}

体重曲線をFig. 1に示した。Control群に比べ高脂肪食 を与えた $\mathrm{HF}, \mathrm{HF}+\mathrm{KH}, \mathrm{HF}+\mathrm{KHL}$ 食群は試験飼料投与 開始から 7 日目ですでに平均值で10～ $15 \mathrm{~g}$ の体重差が生 じ，飼育終了時では50〜 $60 \mathrm{~g}$ の有意な体重増加がみられ た。HF食群と HF+KH食およびHF+KHL食群の間には 体重増加量の有意差は認められなかったものの, 鰹節麹 分解物を添加した HF+KH食群ならびにHF+KHL食群の 体重増加は抑制される傾向にあり, 特にHF+KHL食群 ではHF食群に比べ $15 \mathrm{~g}$ 程度の体重増加抑制がみられた (Table 2 )。

\section{2. 腎周囲脂肪重量および体重に対する腎周囲脂肪重量 の比}

腎周囲脂肪重量は, Control食群に比べ, $\mathrm{HF}$ 食群, $\mathrm{HF}$ $+\mathrm{KH}$ 食群，HF+KHL食群ともに有意に重量が増加した。 そして, $\mathrm{HF}$ 食群と $\mathrm{HF}+\mathrm{KH}$ 食群間では有意差は認めら れなかったものの, HF食群と HF+KHL食群間には有意 差が認められ，KHあるいはKHLを添加することにより 腎周囲脂肪重量は低下する傾向がみられた。また，腎周 囲脂肪重量は摘出量に差があることも考え, 体重あたり の腎周囲脂肪の比率を求めたところ，腎周囲脂肪重量と

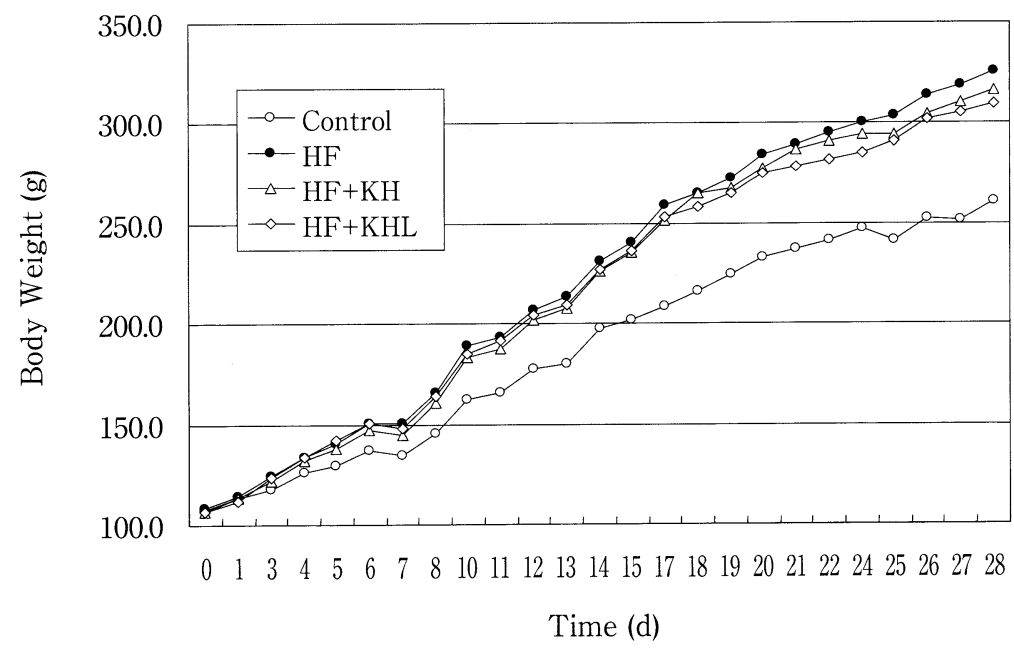

Fig. 1 Growth Curve for Each Experimental Diet Group

Table 2 Body and Circumference (kidney) Adipose Tissue Weights of Experimental Diet Groups

\begin{tabular}{lcccc}
\hline & Control & HF & HF+KH & HF+KHL \\
\hline Final body weight (g) & $260.6 \pm 9.7^{\mathrm{a}}$ & $325.5 \pm 8.2^{\mathrm{b}}$ & $316.3 \pm 10.6^{\mathrm{b}}$ & $309.2 \pm 13.5^{\mathrm{b}}$ \\
Body weight gain (g) & $153.3 \pm 10.6^{\mathrm{a}}$ & $217.0 \pm 9.7^{\mathrm{b}}$ & $209.4 \pm 8.3^{\mathrm{b}}$ & $202.8 \pm 11.3^{\mathrm{b}}$ \\
$\begin{array}{l}\text { Circumference (kidney) } \\
\text { adipose tissue weight (g) }\end{array}$ & $3.4 \pm 0.4^{\mathrm{a}}$ & $10.4 \pm 2.0^{\mathrm{c}}$ & $9.4 \pm 1.0^{\mathrm{bc}}$ & $8.2 \pm 1.5^{\mathrm{b}}$ \\
$\begin{array}{l}\text { Circumference (kidney) } \\
\text { adipose tissue weight }\end{array}$ & $1.30 \pm 0.15^{\mathrm{a}}$ & $3.20 \pm 0.59^{\mathrm{b}}$ & $2.96 \pm 0.30^{\mathrm{b}}$ & $2.65 \pm 0.42^{\mathrm{b}}$ \\
/body weight (\%) & & & & \\
\hline
\end{tabular}

Values represent means $\pm \mathrm{SE}, \mathrm{n}=8$.

Values with different superscript letters are significantly different, $p<0.05$. 
ほぼ一致する結果が得られ，KHあるいはKHLを添加し た場合に体重に対する腎周囲脂肪の重量比は低下する傾 向がみられた（Table 2$) 。$

\section{3. 血清中TG, NEFA, T-Chol, HDL-Chol, LDL-Chol 濃度の比較}

血清中TG濃度は, Control食群とHF食群の間に有意 差は認められなかったのに対して， $\mathrm{HF}+\mathrm{KH}$ 食群ならび にHF+KHL食群ではHF食群に対して有意にTG濃度の 低下が認められた。NEFA濃度は，Control食群に対し て，HF食群は有意な上昇がみられた。HF+KH食群は, Control食群およびHF食群のいずれに対しても有意差は 認められなかったものの上昇が抑制される傾向にあった。 $\mathrm{HF}+\mathrm{KHL}$ 食群は，HF食群に対して有意なNEFA濃度の 低下が認められた。T-Chol, HDL-Chol, LDL-Cholにつ いてはいずれの濃度も 4 群間に有意差はみられなかった (Table 3 )。

\section{4. 肝臟におけるG 6 PDならびにACO活性}

各群の肝臓における 6 期ならびにACO活性の比較 をFig.2（A），(B）に示した。G6 PD活性は，Control 食群がもっとも低く次いでHF食群, $\mathrm{HF}+\mathrm{KHL}$ 食群, HF +KH食群の順で高くなった。Control食群に比べると高 脂肪食を与えたいずれの群も有意に活性は上昇した。ま た， $\mathrm{HF}$ 食群と $\mathrm{HF}+\mathrm{KH}$ 食群間にも有意差が認められた。
$\mathrm{HF}$ 食群と $\mathrm{HF}+\mathrm{KHL}$ 食群間には有意差は認められなかっ たが，KHLを添加したほうがG 6 PD活性は上昇する傾 向にあった。一方，ACO活性についてもControl群に比 べると高脂肪食を摂取した 3 群は活性が上昇する傾向が みられた。その中でも HF+KHL食群はもっとも活性が 高くなる傾向にあった。

\section{考察}

今回，私たちは鰹節タンパク質敖分解物 $5 \%$ \%添加し た $30 \%$ 高脂肪飼料をラットに投与して脂質代謝に及ほす 影響について検討し，鰹節タンパク質麹分解物の食品機 能を評価した。

体重増加量に関しては，HF食群に比べHF+KH食お よびHF+KHL食群において有意差は認められないもの の, 終体重において平均 $10 \sim 15 \mathrm{~g}$ 程度の体重増加抑制傾 向が認められた。その要因として体脂肪の蓄積量の差が 考えられたため，摘出が簡単で比較しやすい腎周囲脂肪 組織を摘出し，その重量を比較するとともに，体重に占 める腎周囲脂肪組織の割合での比較を試みた。その結果， 割合はHF食群 $3.2 \pm 0.6 \%$ に対して, $\mathrm{HF}+\mathrm{KH}$ 食群 $3.0 \pm$

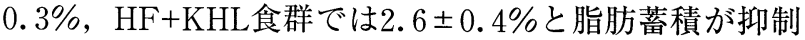
されていた。

次に，血清中の脂質代謝に関するパラメーターである

Table 3 Serum TG, NEFA, T-Chol, HDL-Chol, and LDL-Chol Levels of Experimental Diet Groups

\begin{tabular}{lcccc}
\hline & Control & HF & HF+KH & HF+KHL \\
\hline TG (mg/d $\ell)$ & $98 \pm 7^{\mathrm{a}}$ & $101 \pm 3^{\mathrm{a}}$ & $82 \pm 3^{\mathrm{b}}$ & $71 \pm 8^{\mathrm{b}}$ \\
NEFA (mEq/ $\ell)$ & $0.43 \pm 0.02^{\mathrm{a}}$ & $0.61 \pm 0.03^{\mathrm{b}}$ & $0.50 \pm 0.04^{\mathrm{ab}}$ & $0.38 \pm 0.02^{\mathrm{a}}$ \\
T-Chol (mg/d $\ell)$ & $92 \pm 4^{\mathrm{a}}$ & $94 \pm 6^{\mathrm{a}}$ & $102 \pm 7^{\mathrm{a}}$ & $102 \pm 5^{\mathrm{a}}$ \\
HDL-Chol (mg/d $)$ & $54 \pm 2^{\mathrm{a}}$ & $63 \pm 4^{\mathrm{a}}$ & $67 \pm 6^{\mathrm{a}}$ & $67 \pm 3^{\mathrm{a}}$ \\
LDL-Chol (mg/d $)$ & $20 \pm 3^{\mathrm{a}}$ & $12 \pm 2^{\mathrm{a}}$ & $15 \pm 3^{\mathrm{a}}$ & $24 \pm 3^{\mathrm{a}}$ \\
\hline
\end{tabular}

Values represent means $\pm \mathrm{SE}, \mathrm{n}=8$.

Values with different superscript letters are significantly different, $p<0.05$.
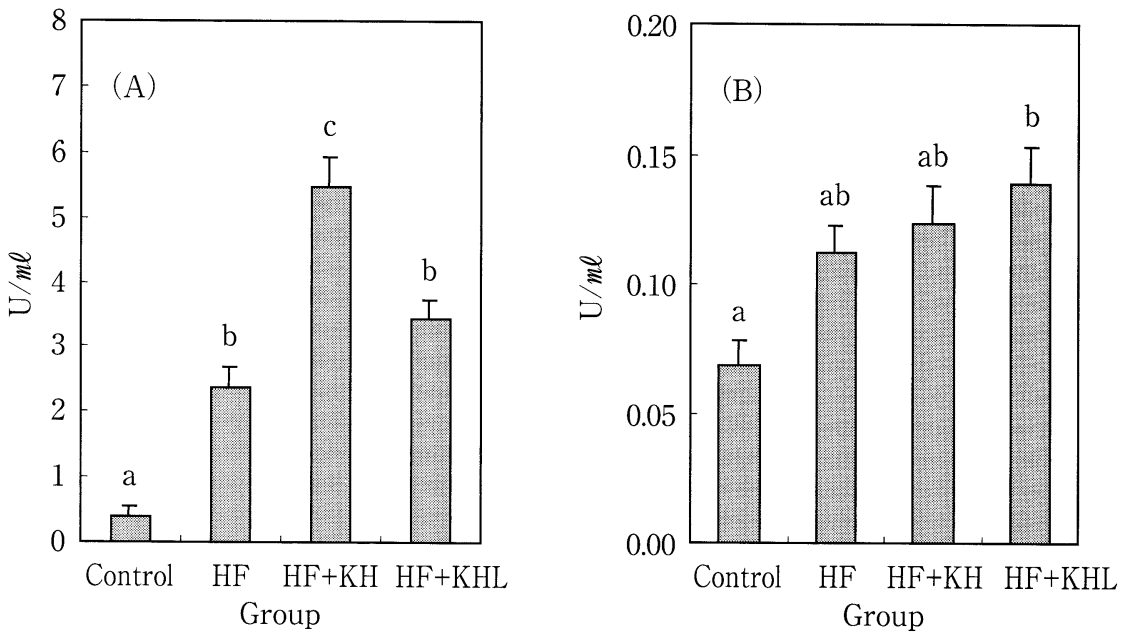

Fig. 2 Effects of KER intake on hepatic G 6 PD (A) and ACO (B) activities Each bar represents mean $\pm \mathrm{SE}, \mathrm{n}=8$.

Bars with different lowercase letters are significantly different, $p<0.05$ 
TG, NEFA, T-Chol, HDL-Cholを測定した結果につい て考察した。TGの測定は, 脂質代謝異常をきたす疾患 の診断, 予後の判定などの指標として実施され高值を示 す病態・疾患としては, 動脈硬化症, 糖尿病, 肥満症, 脳血栓, 脂肪肝があげられる。今回の実験において は，30\%の高脂肪食をラットに投与したことから HF群 では肥満が観察され，TGも高值を示したのに対して， KHおよびKHL群では有意にTG值が低下することが認 められた。

NEFAは, 大部分が脂肪組織に蓄積されたTGが分解 され血中に放出されたもので, NEFAは末梢組織でエネ ルギー源として利用される。血中NEFAは, 脂肪組織の 動員異常や末梢組織での摂取状態を反映するため, 糖・ 脂質代謝異常・ホルモン・神経内分泌異常の指標とされ ている。実験結果からは, HF群食で高值を示し, 高脂 肪食投与の影響がみられたが，KH群では低下傾向，ま た $\mathrm{HF}+\mathrm{KHL}$ 食群では有意に低下することが認められた。 これらのことから, 䚛節タンパク質麦匊分解物には高脂肪 食の摂取により体内に吸収された過剩な脂質の代謝を促 進させ, 脂肪の蓄積を抑制して肥満の程度を軽減する作 用を有することが考えられた。一方, T-CholやHDL-Chol については，群間での差は認められなかった。一般には T-Cholを測定することにより，脂質代謝異常をきたす 疾患の推測ができ, 高值を示す病態・疾患として, 糖尿 病, 動脈硬化症, 肥満症を診断することができる。また, HDLが末梢から肝臓へCholを逆転送して異化させる重 要な役割を果たしていることから, 細胞内に蓄積した Cholの除去機構にも関与し, HDLの低值は動脈硬化, 虚血性心疾患の危険因子とされている。しかしながら, 今回のように 4 週間程度の高脂肪食の摂取では, 体重増 加とTGは上昇するもののT-Cholの上昇はみられず, HDL-CholについてもControl, HF, KH, KHL群の間に 顕著な差が現われなかったと推測された。

今回の実験では, 各群の採食量を合わせる目的で $15 \mathrm{~g}$ /匹/日の制限給餌で行った。制限給慨をした結果として 体重あるいは腎周囲脂肪組織重量および血清中TG濃度 の抑制に何らかの影響を与えたことも考えられたが，す でに私たちは内臓脂肪型肥満OLETFラットを用いた実 験においてAIN76標準飼料および $5 \% \mathrm{KH}$ 添加飼料を自 由摂取させた場合にも KH添加飼料群で体重増加が抑制 されることを見いだしており，制限摂取による実験結果 への影響はなかったものと推察された（論文未発表）。 また, 消化・吸収性の問題についても, 食品として利用 している鰹節タンパク質に由来するぺプチドであるため 試料自体の消化・吸収性あるいは他の栄養素の吸収阻害 に起因する体重増加抑制あるいは血中脂質濃度の上昇抑 制は考え難いと思われた。そこで, 脂肪蓄積量あるいは 血中のTGやNEFAが慳節タンパク質麹分解物の摂取に より低下した要因を肝臓での脂質代謝に関与する酵素活 性に求め検討した。G 6 PDは，NADPをNADPHに還元
し，NADPHは脂肪酸生合成の際に消費される。実験結 果では, G6 PD活性はKH群>KHL群>HF群>Control 群の順に高くなったことからKHあるいはKHLの添加で 肝臓における脂肪酸合成は高まっていることが考えられ た。一方，ACOはペルオキシソームにおける $\beta$ 酸化系の 初発酵素で $\beta$ 酸化系反応全体の律速酵素である。ACOの 活性上昇は， $\beta$ 酸化系を活性化し，これにより脂肪を燃 焼させエネルギーに変換すると考えられる。本実験では, ACO活性はKHL群 > KH群 > HF群 >Control群の順に高 くなっていた。これらのことから, 鏗節タンパク質麹分 解物の摂取により，高脂肪食を投与して吸収された脂肪 酸は，肝臓において脂肪酸生合成により脂肪として体内 蓄積量が高まるものの， $\beta$ 酸化系が活性化されるため工 ネルギーとして利用されたものと考えられた。その結果, 血中TGが低下し，脂肪組織への蓄積量が抑制され，さ らに脂質代謝が改善されたことからNEFAの抑制につな がったものと推察した。大豆夕ンパク質およびペプチド を用いた研究では, 体脂肪蓄積あるいはコレステロール を抑制することが報告されている ク質のプロテアーゼ分解物が血圧上昇抑制作用と伴にコ レステロールを抑制することが報告されている的。これ らのことから, 特定の食品夕ンパク質あるいはそれに由 来するペプチドには脂質代謝を改善する効果を有するこ とが考えられている。すでに血圧上昇抑制効果について は, サーモリシン分解物および筆者らが本試料を用い実 施した研究によりその有効性を確認しているが(6),8), 脂 質代謝に及ぼす影響については報告がない。脱脂したマ グロおよびイワシ筋肉乾燥物をタンパク質源としてコレ ステロール負荷したラットに給与すると血中のT-Chol, LDL-CholおよびTGが低下することを芦田は報告してい るが ${ }^{3)}$ ，そのメカニズムについては解明されていない。 本研究では, 鰹節タンパク質由来のペプチド画分が $\beta$ 酸 化系を活性化させることで高脂肪食投与ラットの脂質代 謝を改善することが推察されたが, 大豆タンパク質由来 ペプチドを用いた研究で報告されているような肝細胞へ の脂肪酸の取り込み抑制あるいは褐色脂肪細胞への直接 的な影響などによる脂質代謝の促進も考えられることか ら，詳細なメカニズムについては今後さらに検討する必 要がある。いずれにせよ, 本試料が体脂肪の蓄積を抑制 し生活習慣病の改善に対して効果を示すことが期待され る。

\section{要 約}

鰹節タンパク質銤分解物（KER）を $30 \%$ 高脂肪食に 添加してラットに 4 週間摂取させ, 脂質代謝を中心に体 調調節機能について評価した。その結果, 高脂肪食のみ を与えたHF群よりもKER麦粎分解物を添加したHF-KH群 およびKERをTFFろ過処理したものを添加したHFKHL群で体重増加の抑制がみられた。また, 腎周囲脂 肪重量においてもKER添加により脂肪重量が減少して 
いた。血清中の脂質については, TGおよびNEFAがKER 銤分解物の添加により有意に低下することが認められた。 しかし，コレステロールについては有意差が認められな かった。肝臓における脂質代謝については，脂肪酸合成 に関与するG6 PD活性は高脂肪食を摂取した群は, い ずれもControl群に比べ高值を示した。一方，ペルオキ シソームにおける $\beta$ 酸化系の律速酵素であるACO活性は, KER趜分解物添加群において HF群よりも活性が高まっ ていた。これらの結果より, KER麹分解物摂取により みられる脂質代謝促進傾向の要因の一つは，ペルオキシ ソームにおける $\beta$ 酸化系の活性上昇が吸収された脂肪を エネルギーへと変換したことに起因するものと示唆され た。

\section{文献}

1 ）吉田宣夫 - 清水博之 - 並木勝治 - 畑原昌明 - 中島淳 一郎：食品工業副産物の飼料化システムの開発 I 。食 品工業副産物を主体とした養豚飼料の配合事例，埼玉 県畜産センター研究報告，1，88～91（1997）

2 ）中島 滋 - 河野竜一・松下精孝・土屋隆英：麺汁製 造過程で生じるかつお節だしかすの栄養価, 日水産 誌，57，2307〜2311（1991）

3 ）芦田勝朗：特集水産物由来の生理活性物質と機能魚 に含まれる体調調節成分，食品工業，36，27〜32 (1993)

4) 関 栄治 - 筬島克裕 - 松藤 寛 - 松井利郎 - 筬島 豊：高圧作用を有するイワシ由来短鎖ペプチドの消化 管プロテアーゼ耐性，日食工誌，43，520～525 (1996)

5 ）末綱邦男：マイワシ筋肉ペプシン消化物からの活性 酸素消去能を有するオクタペプチドの分離同定および その活性，日水産誌，65，92９6（1999）

6 ) Yokoyama, K., Chiba, H. and Yoshikawa, M. : Peptide Inhibitors for Angiotensin I - Converting Enzyme from Thermolysin Digest of Dried Bonito, Biosci. Biotech. Biochem., 56, 1541 1545（1992）

7 ) 田中将行 - 牧野康之 - 池田博明 - 村上昌平 - 井上英 彦・古庄 律 - 安原 義・片岡二郎・片岡榮子：奨油 麹菌を用いた鰹節抽出残椬（KER）の分解について （第 1 報）一有塩下での分解条件検討とその分解液の
調理効果一, 酱研, 30，85～90（2004）

8 ）田中将行 - 池田博明 - 大松佳也 - 井上英彦 - 古庄 律・片岡二郎・片岡榮子：榇油麹菌を用いた鰹節抽出 残椬（KER）の分解について（第 2 報）一無塩下で の分解条件検討とその分解液の生理機能一，滰 研，31，135～139（2005）

9 ）森 豊 - 畑 章一・村川祐一・加藤秀一 - 池田義 雄：内臓脂肪型肥満OLETFラットの体脂肪分布並び に耐糖能に及ぼす大豆たん白質の効果，大豆たん白質 研究会会誌, 17，108～113（1996）

10）福井 嚴・高野圭以・久城英人：生化学的検査卜リ グリセライドとその分画, 日本臨床，43，臨増，340 〜346 (1985)

11）福井 嚴・高野圭以・久城英人：生化学的検査遊離 脂肪酸（FFA）およびその分画，日本臨床，43，臨 増, 347〜351（1985）

12) Lie, R. F., Schmitz, J. M., Pierre, K. J, and Gochman , N . : Cholesterol oxidase - based determination by continuous-flow analysis of total and free cholesterol in serum, Clin Chem., 22, 1627 〜1630 (1976)

13) Gidez, L. I., Miller, G. J., Burstein, M., Slagle, S. and EDER, H. A.: Separation and quantitation of subclasses of human plasma high density lipoproteins by a simple precipitation procedure, $J$. Lipid. Res., 23, 1206〜1223（1982）

14）㴰澤剛則・廣野 晃：グルコース-6-リン酸デヒ ドロゲナーゼ（廣川タンパク質化学 4 酵素 4.1 オキシドレダクターゼ）（廣川書店，東京）, pp. 16〜 20 (2000)

15) Lazarow, P. B., De Duve, C.: A fatty acyl-CoA oxidizing system in rat liver peroxisomes enhancement byclofibrate a hypolipidemic drug, Proc. Natl. Acad. Sci. USA., 73, 2043 2046 (1976)

16）江藤春義・伊藤友美・西岡茂子：乳清タンパク質の アルカリプロテアーゼ分解物による高血圧発症ラット の血圧上昇抑制効果，日栄食誌，52，301～306 (1999)

(平成18年 1 月 23 日受付，平成 18 年 6 月 5 日受理) 